\title{
A Study on Co-Operative Societies, Poverty Reduction And Sustainable Development in Nigeria
}

\author{
Pearse Olugbenga Ezekiel \\ Department of Marketing Lagos State Polytechnic Ikorodu Tel: 08023361083
}

\begin{abstract}
The quest by successive governments in Nigeria and international organizations for accelerated economic growth and the need to enhance sustainable development in the country brought about the introduction of various programs and measures that served as veritable weapon for economic growth. This paper investigate ways cooperative societies act as an instrument for poverty reduction and sustainable national development anchored on income redistribution model. Relevant data and literatures were reviewed to elucidate the roles cooperative societies play in poverty reduction and sustainable national development. The paper argued that cooperative societies offer social protection, enhanced capital formation and employment generation among other benefits and recommends that, for proper effectiveness, cooperative societies should be adequately promoted, nurtured and practiced so as to deliver its potential of being a viable tool for sustainable economic growth.
\end{abstract}

Keywords:- Cooperative societies, poverty reduction, economic growth, sustainable national development, successive governments.

\section{INTRODUCTION}

As global economic meltdown continue to affect the livelihood of people around the world negatively, which has resulted in almost half of the world population living on less than two dollars a day, alleviating this has become a major challenge to the human society. This phenomenon was as a result of a state of short or longterm deprivation and insecurity in basic human needs. World Bank (2000) described this as poverty and sees it as a multi-dimensional phenomenon, with various universally accepted definitions for its economic dimension centers on nature and level of material deprivations which afflict the poor, and distinguishes them from the nonpoor. Sweetman (2002) also described it as lack of income and productive resources sufficient to ensure a sustainable livelihood without hunger and malnutrition, ill-health, limited or lack of access to education and other basic services, increased morbidity and mortality from illness, homelessness and inadequate housing, unsafe environment and social discrimination and exclusion. It is also characterized by lack of participation in decision-making and in civil, social and cultural life. Poverty in Nigeria has given rise to many other serious social problems, some of which, not only impose enormous economic and social costs upon the non-poor and society in general, but also threaten the survival and stability of the society. In these regards, the Governments of Nigeria at different levels and time have designed and implemented numerous programmes targeted at alleviating poverty and improving the living conditions of the people which will bring about a sustainable national development and this include Operation Feed the Nation (OFN), Green Revolution (GR), Structural Adjustment Program me (SAP), Better Life for Rural Women and Family Support Program me (FSP), National Directorate of Employment (NDE), Directorate of Food, Roads and Rural Infrastructure (DFRRI), National Poverty Eradication Program me (NAPEP) and National Economic Empowerment and Development Strategy (NEEDS), Millennium Development Goals, Sure-P, Vision 2020 etc. Unfortunately, the quality of life of major Nigerians had remained unenviable and embarrassingly low, despite the huge budgetary allocations by different levels of governments to these poverty reductions and sustainable national development programs (Orji, 2005). Since government numerous programs had failed to produce the desired results, it is then important to examine the role of non-governmental institutions which offer direct financial and material resources to the poor. One of these non-governmental institutions is Cooperative Societies. In this regard, there is an emerging understanding among leading actors around the world including United Nations (UN), International Labour Organization (ILO), International Cooperative Alliance (ICA), European Union (EU), African Union (AU) and indeed Nigerian Economy Team that cooperative, being the form of organization with local ownership and control, and Net Profit distributed to those who use them is being considered as the enterprise that met all dimensions of poverty (Birchall,2004; 2003 ILO/ICA,2003; Wanyama,, Develtre, \& Pollet, 2008 ).

Cooperative societies are viewed as important vehicles for community development because they mobilize local resources into a critical mass and their structures allow them to be more community-oriented (Fairbairn, Bold, Fulton, Hammond Ketilson and Ish, 1991; Wilkinson and Quarter 1996). A co-operative is an autonomous association of persons united voluntarily to meet their common economic, social, as well as cultural needs and aspirations through a jointly owned and democratically controlled enterprise.(Committee for the 
Promotion and advancement of Cooperatives, COPAC 1999). Cooperatives have been an effective way for people to exert control over their economic livelihood and this provide opportunity of achieving one or more economic goals in an ever increasing competitive environment. Cooperative society has become weapon that is used to lessen the effect of poverty on the populace in developing nation as Nigeria. Successful cooperative business can be found in virtually every industry in Nigeria. for instance in Lagos alone, there are about 12,000 registered cooperative societies across public and private sector of the economy with 39,000 trustees managing over 2 million members in all economic and social strata of the state with an asset base of over N40 billion and landed properties (Lagos State Ministry of Agriculture and Cooperative, 2013). A number of studies have been undertaken in and outside the country to indicate the relationship between cooperative societies, poverty reduction and sustainable national development across different countries. While a large number of them strongly believe that Cooperative Societies are major catalysts for alleviating poverty (Birchall 2004, Adebayo et al 2010, Leistritz 2004, Wanyama, Develtere,\& Pollet 2008, Allahdadi 2011, Aref 2011, Bhardwaj 2009, Igen 1984, Tar 2008, Izekor \& Afufohai 2010, Otto \& Ukpere 2011, Adebayo \& Yusuf 2004) a fraction of them believe otherwise suggesting that Cooperative Societies cannot help reduce poverty (Stewart 2005, Berner \& Phillips 2005, Attwood \& Baviskar 1989, Holmen 1990). In light of the foregoing, it is not certain whether Cooperative Societies currently has been practiced in the country can help to enhance a sustainable economic development. Therefore, the aim of this paper is to examine the fundamental role cooperatives play in poverty reduction and also offer suggestions on how to improve it activities towards enhancing a sustainable national development. In doing this, the paper contributes to the extant literature on the role of Cooperatives by extending the frontier of knowledge. Policy-makers, scholars and practitioners in Nigeria will find the findings of this study useful in organizing and providing support to Cooperatives in different states. This paper is organized to accommodate the introduction, literature reviews, theoretical framework and policy implementation and discusses the conclusion and recommendations.

\subsection{CONCEPTUAL FRAMEWORK}

\section{LITERATURE REVIEW}

\subsubsection{POVERTY REDUCTION}

World Bank (2000) describes poverty as a multi- dimensional phenomenon and sees it as a state of short or long-term deprivation and insecurity in basic human needs. Chamber Universal Learners' Dictionary defines poverty as the condition of being poor. Poverty is a multi-faced phenomenon that actually hinders the satisfaction of human basic life requirements, i.e. the condition that deprives the individual the necessities for existence such as good food, potable water, shelter, clothing as well as those that bother on the security of life as health, education opportunities and freedom (spencer, 2005). Poverty manifests not only in the lack of adequate access to physical capital but also entailed deprivation of natural, social as well as human capital; natural capital in the sense of land, water, animals, trees and minerals while physical includes tools, machines, human capital as well as land and building improvement (Ellis,2000). In fact, poverty is a condition whereby an individual is unable to generate sufficient income to secure the basic standard of living and this situation manifest in all sphere of life in most post-colonial African countries like Nigeria. Alleviating this phenomenon has become the biggest challenge to the world at large because of it multi- dimensional, deep-seated and complex nature. Therefore, there has been search for such community based approaches that can overall fight against multidimensional poverty and also generates confidence in the communities after numerous pro - poor growth approaches such as mercantilists approach on foreign trade, classical economists approaches and industrial revolution as well as basic needs and capabilities/entitlements approaches failed to generate adequate results to compliment their effort (Ijaiya, 2002, Boeniniger 1991, Woolcock and Narayan 2000, United Nation 2004). World Bank (2004) describes poverty reduction as the means of strengthening the domain of transferability. Identifying asset, creating access to the available asset and enhancing its transferability to command welfare. Poverty reduction should necessarily incorporate resolving social, economical, cultural and psychological barriers (Bhardwaj, 2009).Ihenacho, Chikaire, Ejiogu-Okereke, Oguegbuchulam, Osuagwu and Obi (2012) posited that reducing poverty requires attacking many interrelated forces that keep poor people in a state of deprivation as well as expanding people's access to participation in decision- making process and knowledge, training and markets as well as other productive resources for income generation such as land, technology, credit and adequate information needed. Poverty reduction refers to all efforts made by governments, organization and corporate individuals that attempt to put, push or pull the poor out from the nexus of poverty or put them above poverty line. According to Ogwumike (2001) who stated that the poverty reduction measures put in place in Nigeria either during pre - SAP era, SAP and democratic era focuses more attention on economic growth, basic needs and rural development strategies. Any given poverty reduction mechanism must enhance capabilities which permit greater amount of output from any level of input, while the increased output must go a long way to increase standard of living of the people and thereby reduces poverty (Atoloye 1997).The success of any poverty reduction measures are determined by some major factors as; a well 
defined property rights for landholder and informal entrepreneurs, well developed markets that strengthens savings mobilization, promote a sound macroeconomic stability, security of life, moderate size of government, efficient civil services, impartial regulatory, good governance with emphasis on tackling corruption, inefficiency and enhance accountability(Calamitsis 1999, Hernandez - Cata 1999, Quattara 1999 and Dollar and Kraay 2001). . In other developing nations, cooperatives have significantly contributed to mobilization and distribution of financial capital, created employment and constituted platform for education and training, social welfare as well as other socio-economic problems associated with poverty (Tanzania Federation of Cooperatives,2006).

\subsubsection{COOPERATIVE SOCIETIES}

Cooperatives societies are the first and foremost, voluntary business associations formed by people of limited means through contribution of share capital that forms the basis of sharing out the profits that accrue from the business or use as dictated by its members, reasons why it has to be democratically manage by the members themselves. ICA (International Cooperatives Alliance) defined cooperatives as an autonomous association of persons united voluntarily to meet their common economic, social and cultural needs and aspirations through a jointly owned and democratically-controlled enterprise. Cooperative is a group-based and member-owned business that can be formed for economic and social development in any sector (Ohio Cooperative Development Center, OCDC, 2007). The International Labour Organization (ILO) sees cooperative as an association of person usually of limited means, who have voluntarily joined together to achieve a common economics and through the formation of a democratically controlled business organization, making equitable contribution to the capital required and accepting fair share of the risks and benefits of the undertaking in which members actively participate. Cooperative is a catalyst for local entrepreneurial growth; because it retains within the communities in which they operate the capital that they mobilize themselves, as well as surplus derived from outside transactions, both accumulating for further entrepreneurial development. This opinion supports the view of Olaleye (2004) who sees cooperative societies as a business voluntarily owned and controlled by its members and operated for them and by them on a non-profit or cost basis. Cooperative enterprises provide the members means whereby a significant proportion of humanity is able to take into its own hands the tasks of creating productive employment, overcoming poverty and achieving social integration and continue to be an important means, common to all are the co-operative values of self-help, self-responsibility, democracy, equality, equity and solidarity. According to DFID (2005), cooperatives have four main characteristics: first, they are formed by groups of people, who have a specified need or problem. Secondly, the organization is formed freely by members after contributing to its assets. Thirdly, the organization formed, is governed democratically in order to achieve desired objectives on equitable norms, and fourthly, it is an independent enterprise promoted, owned and controlled by people who are members to meet their needs. Although, the poor have very weak transferable assets or lack of recognition for the assets they have i.e. they lack adequate welfare exactly where the relative concept of cooperatives focuses.

\subsubsection{SUSTAINABLE DEVELOPMENT}

Sustainable development rose to significant importance after it was used by the Brundtland Commission in 1987 report "our common future", in the report the commission coined what has become the most often-quoted definitions of sustainable development which opined that sustainable development is that development that meets all the needs of the present without compromising the ability of future generations to meet their own needs. Sustainable development concept is based on the assumption that societies need to manage three types of capital (economic, social and natural) which may be non-substitutable and whose consumption might be irreversible (Daly 1991). Sustainable development is seen as an organized principle for human life on a finite planet. It posit a desirable future state for human societies in which living conditions and resource- use meet human needs without undermining the sustainability of natural system and the environment so that future generations may also meet their needs. This concept tied together concern for the carrying capacity of natural system with the social and economic challenges faced by humanity; it was employed in the 70 's to describe an economy in equilibrium with basic ecological support systems.

This concept "sustainable development" can as well be broken into three constituent domain such as environment sustainability, social sustainability and economic sustainability which required a growth in the gross domestic product that involves improvement in the quality of life for many but particularly for the affluent. During the last few years, successive government have tried to measure and monitor the proximity to what they consider sustainability by implement various policies and programs such as SURE-P, NEEDS,SMEDAN, Green revolution, Millennium development goals, Vision 2010 as well as Vision 2020 just to defined Sustainable development in the context of poverty reduction. In the light of these, the paper intends to adopt a theoretical explanation of views of various authorities in expressing the relationship that exist between cooperative societies, poverty reduction and sustainable economic development. 


\section{THEREOTICAL FRAMEWORK 3.1.0 COOPERATIVE SOCIETIES, POVERTY REDUCTION AND SUSTAINABLE NATIONAL DEVELOPMENT}

In other to reduce poverty levels in most developing nations over the years, various schools of thought have advocated a number of measures starting from the era of mercantilists with emphasis on foreign trade as a vehicle for economic growth and poverty reduction, to pro-poor growth approach, forced-drift theory, classical economists theory lead by Adams Smith up to basic needs and entitlement approaches as well as community self help, good governance and human right approaches of 1980s to 2000s. The theoretical framework of this paper is anchor on income redistribution approaches which advocated re-distribution of income and emphasis that poverty can better be reduced if radical redistribution of income is allowed to take place in view of the interlocking power and self -interest of the rich and the bureaucracy in the handling of each nation resources Chenery, Ahluwalia, Bell, Dulloy \& Jolly (1974). This were done to address the inadequacy in the policymakers response to the growing level of poverty and unemployment with a desire to provide relevant solution to the problems associated with poverty in the land. In Nigeria, governments at different levels and various other agencies of concern have adopted various strategies at one point or the other so as to reduce this menace and enhance sustainable national development without much result which necessitated them to look for a more community base approach as cooperative societies that can tackle all dimensions of poverty. Findings from previous authors base on their research studies have also showed that cooperatives is a viable mechanism that can aliemeorate the effect of this socio-economic vices called poverty in most African counties and beyond. Oseni, Ogunniyi \& Sanni (2012) exalted that, although members might join cooperative for various reasons but the major desire is to get cheap loans and capital that can be invested in the acquisition of fixed assets as savings for the rainy day. Karlyle (2005) also concluded that a well developed cooperative model of economy with ranges of potentials can offers required direction for humanity and the challenges of natural, economic and community integration could well be mastered. This will go a long way in engaging ourselves in building a long lasting, endurable attainable future for our children and grandchildren that made up the society at large. Ihenacho, Chikaire, Ejiogu-Okereke, Oguegbuchulam, Osuagwu and Obi (2012) also concluded in their studies that; job creation, facilitation of financial services, educational support, labor exchange as well as mutual aids are the fundamental poverty reduction and sustainable national development strategies of major cooperative societies in most African countries like Nigeria and therefore encourage the promotion of cooperative activities vigorously. The need to expand educational services in all aspect of cooperative management and the desire to protect the investment of the citizenry couple with it relevance's to socio-economic development of the state prompted Lagos State government to established cooperative college in Agege area of the state to cater and provide a short - duration capacity building intervention to officials of cooperative societies in the state metropolis (Lagos State Ministry of Agriculture and Cooperative, 2013). All these pointed to the fact that cooperative is a poverty reduction mechanism suitable for delivering a sustainable results if well-articulated. Olaleye (2007) also posited that for proper effectiveness and efficiency, poverty reduction strategies of cooperatives need to be annexed so as to remain focus on provision of financial support, loans which can further be redistributed among the members. Izekor and Alufohai (2010) are of the opinion that well organized cooperative societies is found to be effective credit delivery, Tar, (2008) also believed on research that cooperatives generate substantial employment directly while they also empowered to own business with a multiplier effect on country economy growth and poverty reduction. Otto and Ukpere (2011) are also of the opinion that cooperative societies encourage members in the area of capital formation for investment purposes and poverty reduction strategy. Oki (2008) is of the view that cooperative societies should move away from mere contribution and lending of money to members to that of creating returns through engagement in business activities to compliment their effort in sustaining growth and poverty reduction. Shekari (2012) posited that many household who are cooperative members earned and live below poverty line in both public and private sector have their deduction carried out by the employers at source from the salaries which ensure prompt deduction and loan disbursement to members as needed. Dogarawa (2005) also posited that for cooperative societies to leave up to its expectation of viability and sustainability it must be run on two inter-related goals, such as economic viability and innovative enterprise so as to be effective in poverty reduction. While Adekunle and Henson (2007) were also of the opinion that entrepreneurial alertness is imbibe in the consciousness of members as soon as they become members which go a long way to give social protection to the members. Nweze and Onuoha (2001) also emphasis in their studies that government should be less hostile to cooperatives but supportive to its operation by eliminating operational policies that might be inimical to the operation in order to emphasis poverty reduction. Allahdadi (2011) also posited in his study that cooperatives provided the opportunity for the poor to raise their income and made significant contribution to poverty reduction strategy in Marvdasht Iran. Major roles and potential of cooperatives societies were also examine and concluded to include; enhancing access to market and capturing more of the value chain, assisting in getting better deal at various stages of production and distribution, contributing significantly to the mobilization and distribution of financial 
capital by creating employment and income generating opportunities which ultimately bring about poverty reduction (DFID 2010, Wanyama, Develtere, \& Pollet 2008, Simmons \& Birchall 2008). Fafchamps \& Minten (2002) also emphasis in their studies that cooperative societies create social capital among the members at a greater rate than among shareholders of investor - owned firms and the amount of social capital within the organization theoretically will enhance economic efficiency and enhance long term success with monumental impact on poverty reduction. All these posited to the fact that well articulated cooperative societies runs on the basis of the world acclaimed Rochalde principles provide veritable opportunities to members of the societies which significantly results in alleviating their poverty levels and enhancing national development correspondently. A well managed Cooperatives societies can go a long way in contributing to poverty reductions and enhance national development in so many ways as exalted by various authorities on their research work, the major area of concentration for this study includes;

\subsubsection{COOPERATIVES LOANS AND CAPITAL FORMATION}

Cooperative loans are the most critical aspect of cooperatives benefit and activities. There are a number of previous studies that have commented on this; Tsekpo,(2007) emphasis that cooperative societies enhances capital formation which go a long way in expanding the investment profile of its members, including the acquisition of property for future gain, educational support for their children which is seen as an investment in intellectual capital with the hope that the child will be gainfully employed and it will transform to future gain for him, creation of capital goods or goods capable of producing other goods. Saving habits are encouraged tremendously which ultimately put the members in better position to tackle avoidable emergencies. Wanyama, Develtere \& Pollet (2008) also posited that Cooperatives is increasingly becoming a major source of productive resources that are made available to their members for a variety of uses; the most common is the incomegeneration opportunities make possible due to growing abilities of these cooperatives to mobilize substantial savings from which members can borrow. For instance, it is observed that major part of the cooperative loans taken by members in Lagos State Polytechnic Cooperative Societies are use to support informal businesses they established in other to supplement their wage and salary. Cooperatives loan comes in various form to members of a society, it can be in form of major capital given based on the level of contribution which are majorly substantial enough and it can also be emergency or soft loan that are taken to take care of contingencies as quick as possible, soft loan is not as substantial as the major capital loans. Chaitra (2010) observed that, this major reason contributed to the growth of some types of cooperative societies peculiar to various sector of the economy for instance, Thrift, savings and loan cooperative societies among the working class within the economy so that what can't be achieved individually can as well be achieved collectively. The loans collected are use to undertake various project that enhance assets acquisition, increased their access to major items that may not ordinarily be access if not cooperatives. It also goes a long way to strengthening the domain of transferability i.e transferring out the assets to command the welfare needed (Bharadwaj 2012). Oseni, Ogunniyi and Sanni (2012) also posited that the paramount reasons to members of cooperatives are the access to cheap loans for acquisition of assets and saving for the raining day.

\subsubsection{EMPLOYMENT IMPACT OF COOPERATIVE SOCIETIES}

Various authors have submitted on the major employment impacts of cooperatives societies both in developed, developing and under- developed nations of the world. Wanyama et.al (2008) opined that Cooperative societies create employment opportunities in major three ways starting from the view of the personnel directly employed to run the ventures of different levels of the societies and the various government and non- governmental agencies providing support services to the cooperatives e.g ministries, departments and cooperatives college, to the offer of self employment it gives to members whose participation in economic activities substantially guarantees decent income, as well as indirect employment base on the spillover effect of cooperatives activities on non-members whose income come only from the transactional relationship with the cooperative ventures. Of all the three stated, direct wage employment presents the least contribution to employment generation even though data have shown the substantial numbers of people are directly been engaged at various government and non- governmental agencies. (Lagos State Ministry of Agriculture and Cooperative, 2013). Thuvachote (2011) also posited that cooperative societies create and maintaining employment in rural and urban areas, employment opportunities are created as a production enterprise that directly employed their personnel and as service provider that indirectly generated employment to their members. This exclude the season labor who are engaged specially to undertake specific tasks like working in the mills, block industry e.t.c. cooperatives facilitate employment through members' owned enterprises contributing substantially to the country gross domestic product

(Wanyama,2008). Our evidence from the field suggests that the sector is actually employing more. Wikipedia (2006) and Levin (2002) emphases that cooperative societies employed more than 100 million men and women worldwide. With the ideas that employment were also created with the opportunities to upgrade skills through 
workshops and courses that are offer to members and the communities in which they dwell. Social protections which have been seen as the sole right of some wealthy fewer in the society are substantially guaranteed to avoid the vagaries of unexpected calamities that normally derail livelihood. Curriculum of institutions is now being structured to accommodate the studies of cooperative activities which after learning it becomes a carrier for them and the bases of being employed tomorrow, for instance cooperative colleges have been established to cater for the training and personnel development of these institutions with the multiplier effect on the economy of the nation (Lagos State Ministry of Agriculture and Cooperative, 2013). Psychological values of seen oneself as a partial owner of a business running on sound management principles, given corresponding benefits in form of dividend the members receive from the cooperative transactional activities always enhance the members' morale of being part of the society in which they live Karlyle (2005).

\subsubsection{SOCIAL PROTECTION VALUES OF COOPERATIVE SOCIETIES}

With social protection, we mean societal security mechanisms that can respond to unexpected socioeconomic scarcity and major risks that people normally encountered in their livelihoods. Post colonial African countries relied mostly on mutual aid in securing individual from misfortune or calamity that are sometimes beyond what individual can control or handle. A cooperatives society possesses potentials to contribute to poverty reduction in rural areas which will generate confidence in rural community. With cooperative, income, social status and capacity of the household will increases and all the benefit in form of services, access or cash are converted to welfare generation. Bouman (1995) posited that the mutual aids can be express to includes, helping families, kin and villager to ease the burden and lessen the shock of death that might visit manhood by meeting the expenses of funerals, weeding and other social activities.

On the other hand, corruption and the institutional weaknesses of the African state hindered the establishment of organized and state-run social protection systems catering for the society, in this situation, it is only the fewer wealthy individual that actually benefited in the social protection system privately provided by the insurance companies leaving the less or the poor to savage their own course and provide for themselves which have quite exposed the poor to vagaries of unexpected calamities that can derail livelihood. The emergences of cooperative societies have acted as networks of securing individuals or members from all these unanticipated circumstances. Cooperatives also offer emergency and instant loan to members to solve unexpected problems which have actually been acting as fall back for members to quickly respond to unanticipated socio-economic problems like sickness, an accident, food shortage, crop failure, financial snag among others which have the potential of disrupting livelihood.

Furthermore, some cooperative societies make provisions for social fund from their annual contributions to provide for communal needs as well as some basic social services needed within the community were they operate. Provisions for food security is one of the fundamental social protection roles of most cooperative societies with the broader objectives of fighting ignorance and poverty with the package of services such as training, inputs needed by members, financial lifeline, marketing opportunities for their outputs. Each element mentioned met a specific need but the synergy between all of them goes a long way to promote development and improve members living conditions. Cooperatives also safeguard the jobs of the members most especially where trade union provide the foundation for the movement e.g Taxis drivers or Cab operators cooperative societies always assist the members in the provision of some necessities required for smooth running of their business with a view of collectively secure their job by combating unemployment, fighting ignorance and strengthening the unity of members. In all these ways, cooperative societies have increasingly protecting their members from all avoidable calamities that usually disrupt human hood.

\section{CHALLENGES OF COOPERATIVE SOCIETIES}

In most part of the world, cooperative societies remain in fluxes which are majorly faced with one or more problems ranging from the crises of ideology, capital formation, problems of acceptability and credibility as well as crises of management (Taimni, 1997). Five major challenges of cooperative societies have also be identified by Cheney (1995) to includes cultural transformation, competition and expansion, wage solidarity, centralization and reorganization, and policies and programmes of increasing productivity and participation. While on the other hand Groves (1985) emphases that the major problems of cooperatives are how to strike a balance between efficiency and democracy as the major part of cooperative business. i.e imbibing good business practices and the social purpose of a community of people, making it an organizations with a human face and therefore difficult to manage. Laidlaw (1974) emphasis that whenever cooperatives tend to strive for efficiency they try to imitate other businesses but in the pursue of social functions they possess the features that differentiate them from other organizations which make it a very difficult business to manage. Education makes people easy to lead and govern but difficult to drive and enslave, educating cooperatives members in this post colonial African countries like Nigeria is always a challenge to the organizations and the governments. Even cooperatives choice of business suitable for it purpose have become a fundamental challenges to the survival of 
the organizations. Cooperative societies also suffers from internal handicap of it own making because of the social, voluntary and democratic nature of it business which handicapped them from imposing strict measures and disciplines on themselves and prefer to act on common consent. Other major challenges also include;

Inadequate financing

Mismanagement of resources by the management committee (board of directors).

Unqualified/inexperienced management committee.

Uncommitted membership.

Lack of clear policy guideline on cooperatives management.

Outdated/inherited colonial cooperative law that deters cooperative autonomy.

Government altitude towards cooperative development.

Lack of infrastructural facilities like regular and stable electricity, accessible roads, pipe - borne water. In other to tackle the above-mentioned challenges, cooperatives should increasingly focus on directly enhancing socio-economic conditions of their members by engaging in value-added operations ,i.e activities that have significant impact on the wellbeing of members and also encourage participations through improved services and adhere strictly to the principles of openness, honesty, prudency and caring for the environments as well as the community. Cooperatives should make optimum use of the available resources, enhance efficiency while providing quality services to its members using the most acceptable and friendly approaches to mobilize fund or capital and develop a fundamental measures for it redistribution among the needy members.

\section{CONCLUSIONS AND RECOMMENDATIONS}

The major purpose of discussion is to emphasis or to demonstrate the major contributions or roles cooperative societies can play in poverty reduction and sustainable national development in post colonial Africa countries like Nigeria. it is evidence that cooperatives have significantly contributed to wealth redistributions, poverty reductions and sustainable development from human livelihood perspective. It is obvious that reduction of poverty is all about improving poor conditions and generation of a sustainable command of welfare. It is proved that cooperative is community business that can potentially support breaking down the vicious cycle of poverty. Given that cooperatives is open to all persons without ethnic, class or professional biases most especially rural settings offered employment opportunity for both members and non-members alike. The incomes generated are used to meet household needs and also to ensure income- generating capacity of individuals by investing in educational, health requirement and socio well-being of individuals and household. Furthermore, cooperative societies enhances capital formation which go a long way in expanding the investment profile of its members, including the acquisition of property for future gain, cooperative societies also create and maintaining employment in rural and urban areas, employment opportunities are created as a production enterprise that directly employed their personnel and as service provider that indirectly generated employment to their members. Cooperatives also offer emergency and instant loan to members to solve unexpected problems which have actually been acting as fall back for members to quickly respond to unanticipated socio-economic problems like sickness, an accident, food shortage, crop failure, financial snag among others which have the potential of disrupting livelihood. Cooperatives are therefore becoming the preferred mechanism or tools for mediating people access to major resources that they usually utilized to participate in other activities through which they earned a living. It is base on this that cooperative societies are contributing to poverty reduction and sustainable national development. Government should therefore be sincere regarding cooperative formations, management and utilization of their resources for the use of the members and the societies at large. The author also recommended that for effective and efficient delivery of it potential government and political representative must ensure that the appropriate business environment, legislation and infrastructural framework are created to facilitate the successful establishment and development of cooperative societies across all discipline and adequate awareness should be given for it acceptability. Since food production is not keeping pace with population growth in most African countries (Nigeria) which have resulted in a wide gap between demand and supply of most essential items and the growing advocacy for sustainable food security. Agricultural cooperatives should be widely encouraged so as to achieve this mandate. Nigeria governments at different levels should also establish and articulate various other programmes like youth in cooperatives, women in cooperatives e.t.c as it was done in the seventies in Jamaica with so objectives of providing gainful employment for the youth in agricultural and other related pursuits, harness youthful talents and skills into productive agriculture so as to able to boast local production for sustainable socio-economic development.

\section{REFERENCES}


[1]. Adebayo, S.T., Chinedum, O.H., Dabo, C.S.P., \& Pascal, H. (2010). Cooperative Association as a Tool For Rural Development and Poverty Reduction in Rwanda: A study of Abahuzamugambi ba Kawa in Maraba Sector Educational Research, 1(11), 600-608.

[2]. Adedayo, A., \& Yusuf, O.R. (2004). Cooperatives and Poverty Alleviation in Alleviation and food Production in Sub-Saharan Africa: Seminar paper on Risk Assessment of Global Agrifood Production Chains. Department of Economics and Management, University of Helsinki, Finland.

[3]. Adedayo, A., \& Yusuf, O.R. (2004). Cooperatives and Poverty Alleviation in Rural settlement of Kwara State Nigeria. vol. 19. No. 2.

[4]. Adekunle, B., \& Henson, S.J. (2007). The effect of cooperative thrift and credit societies on personal agency belief, A study of entrepreneurs in Osun State Nigeria: African Journal of Agricultural research, 2(12), pp. 678-686.

[5]. Allahdadi, F. (2011). The Contribution of Agricultural Cooperatives on Poverty Reduction: A Case Study of Marvdasht, Iran: Journal of American Science. 7(4), 22-25.

[6]. Anyawu, J.C. (1997). Poverty in Nigeria. Concepts, Measurement and Determinant in Poverty Alleviation in Nigeria: A Paper presented of the annual conference of Nigeria Economic Society held in Ibadan. Pp17-2.5.

[7]. Aref, A. (2011). Rural cooperatives for Poverty Alleviation in Iran. Life Bank, Washington, DC.

[8]. Attwood, D.W., \& Baviskar, B.S. (1989). Who shares: Cooperatives and rural development Oxford University Press, Delhi.

[9]. Berner, E., \& Phillips, B. (2005). Left to their own device: Community self-help between alternative development and neo-liberalism", Community Development Journal.

[10]. Bhardwaj, B. (2009). Poverty as a cause and effect of corruption. Souvenir. Kathmandu: Commission for Investigation on Abuse of Authority.

[11]. Birchall, J. (2003). Rediscovering the Cooperative Advantage Poverty.Reduction through Self-help: Cooperative Branch, International Labour Office, Geneva.

[12]. Birchall, J. (2004). Cooperatives and the Millennium Developments goals. Campaign Against Poverty. International Cooperatives Alliance, Geneva.

[13]. Chambers, R., (1996). Rural Development: Putting the Last First. Longman.

[14]. Chikaire, J., Nnadi, F. N., Osuagwu, C.O., Oguegbuchulam, M. N., Oparaojiaku, J., \& Jamilu, A.A. Committee for the Promotion and Advancement of Cooperatives (COPAC) 1999. The Contribution of cooperatives to the Implementation of the World Summit for Social Development Declaration and Programme of Action: First Session of the Preparatory Committee for the Special Session of the Sand

[15]. Department for International Development (DFID) 2005. How to Leverage the Co-operative Movement for Poverty Reduction. DFID Growth and Investment Group. How to note, May 2005 from http://www.caledonia.org.uk/papers/How-to-cooperatives-DFID-2005.pdf (retrieved June 10, 2011)

[16]. Dollar, D .,\& Kraay, A.(2001). Trade, Growth and poverty. World Bank policy Research. Working paper 2615.

[17]. Dogarawa, B. (2005). The role of Cooperative Societies in Economic Development: MPRA paper No. 23161. Available at www.mpra.ub.unimucchem.da/23161.

[18]. Ellis, F. (2000). Rural Livelihoods and Diversity in Developing Countries, Oxford: Oxford University Press.

[19]. Fairbairn, B. J., Bold, M., Fulton, L., Hammond K., \& Ish, D.(1991). Co-operatives and Community Developmnent, Economics in Social Perspertive. Saskatoon Saskatchwan, Canada: Centre for the Study of Cooperatives, University of Saskatchewan.

[20]. Fefchamps, M., \& Minten, B. (2002). Social capital and the firm: Evidence from agricultural traders in Madagasca. In C. Grootaert, \& T.V. Bastelaer (Eds.), The role of social capita in development: An Empirical assessment (pp. 125-154). New York: Cambridge University Press.

[21]. Holmen, H. (1990). State, Cooperatives and Development in Africa. The Scandinavian Institute of African Studies. Uppsala.

[22]. ICA (1995). Statement on the Cooperative Identify. International Cooperative Alliance

[23]. Ijaiya, G.T. (2002). The Role of the informal sector in minimizing poverty in Ilorin metropolis. Unpublished Thesis, department of economics, Usman Dan Fodiyo University, Sokoto,Nigeria

[24]. Ijere, M.O. (1977). The prospects of Employment Creation through Cooperatives in Nigeria: Journal of Rural Development and Cooperative Studies, 2(2): pp 70-77.

[25]. ILO/ICA (2003). The Role of Cooperatives in Designing and Implementing improved Socio-economic conditions of Beneficiaries in Southwestern Nigeria: University of Ibadan, Nigeria.

[26]. Izekor, O.B., \& Alufohai, G.O. (2010). Assessment of Cooperative Societies Effectiveness in Agricultural Credit Delivery in Ikpoba Okha Local Government Area, Edo State, Nigeria: African Journal of General Agriculture 6(3): 139-143. 
[27]. Leistritz, F. L. (2004). "Measuring the economic impact of producer cooperatives" in Merrett C.D and Walzer N. (Eds) Cooperatives and Local Development: Theory and Applications for the $21^{\text {st }}$ century, M.E Sharpe Inc., New York

[28]. Levin, M. (2002). The promotion of cooperatives, ILO Cooperatives Branch, at www.ica.coop/europe/ra2002/speech

[29]. Ogwumike, F.O. (2001). Appraisal of Poverty and Poverty Reduction Strategies in Nigeria. CBN Economic and Financial Review. Vol.39. No.4:45-71.

[30]. Okunmadewa, F. (1999). Poverty Alleviation in Nigeria. Invited Paper Presented at Policy Seminar on Poverty Alleviation in Nigeria Organized by Federal Office of Statistics: Held between August $2^{\text {nd }}-5^{\text {th }}$ 1999, Abuja, Nigeria. pp. 22-25.

[31]. Olaleye, Y. L., \& Adekola, G.(2006). Impact of co-operative societies on poverty alleviation: A study of three main co-operatives societies in Ibadan, Nigeria, Education for Today, 6:109-120.

[32]. Orji, J.I.(2005). An assessment of Poverty reduction Programmes in Nigeria as a Development Strategy, 1970-2005. Ph.D. Thesis, Unpublished. The St. Clements University, Turks and Caicos Island.

[33]. Oseni, J.O. (2007). Economic Analysis of Mushroom Marketing as a Coping Strategy for Poverty reduction in Ondo State, Nigeria. African Crop Science Conference Proceedings. 8 pp. 1255-1260. From http://www.acss.ws/upload/XML/Research306.pdf (retrieved March 2, 2011).

[34]. Osigwe, T. (2011). Cooperatives- A vehicle for Rural Development: The Case of Ahiazu Mbaise Area of Imo State, Nigeria: Journal of Nature and Science, 9(11): 6-11.

[35]. Otto, G., \& Ukpere, W. (2011). Credit and Thrift co-operatives in Nigeria: A potential source of capital formation and employment: African Journal of Business Management Vol. 5(14), pp. 5675-5680. Psychologia, 10 (1): $72-84$

[36]. Spence, W.R. (2005). Power Structures and Capacity Asset of Macro-poverty Analysis, Development Policy Review.

[37]. Stewart, F. (2005). Group and capacities: Journal of Human Development

[38]. Sweetman, C., (2002). Editorial, Gender and Development 10:24-4.

[39]. Tar, T. (2008). Report on the Workshop on $8^{\text {th }}$ ICA Africa Regional Assembly, Abuja.

[40]. United Nations (2004) Guidelines for a Human Right Approach to Poverty Reduction Strategies. High Commissioner for Human Rights. New York: United Nation.

[41]. Wanyama, F.O., Develtere, P., \& Pollet, I. (2008). Encountering the Evidence: Cooperatives and Poverty Reduction in Africa. Working Papers on Social and Co-operative Entrepreneurship WP-SCE 08-02-2008.

[42]. Woolcock, M., \& Narayan, D. (2000). Social Capital: implication for development Theory, Research and Policy. World Bank Research Observer.

[43]. World Bank (2000). World Development Report, Washington D.C. 